\title{
Cattle Distribution on Mountain Rangeland in Northeastern Oregon
}

\author{
R.L. GILLEN, W.C. KRUEGER, AND R.F. MILLER
}

\section{Abstract}

Cattle grazing distribution patterns were studied directly through observation and indirectly through plant utilization during 3 summer grazing seasons under continuous and deferred-rotation grazing systems. Small riparian meadows were the most preferred plant communities. Meadows covered 3-5\% of the total observation area but $24-47 \%$ of all cattle were observed in those plant communities. Logged forest communities ranked second in animal preference when available. Rebatively open $P$ irus ponderosa-P seudotsuga menziesii plant communities were the most preferred forested habitats. Deferred grazing equalized cattle use between logged areas and $P$. ponderosa-P. menziesii forests and increased cattle use of riparian meadows. Heavily forested sites were least preferred by cattle. Slope gradient was the only physical factor consistently associated with cattle grazing distribution. Water distribution was not correlated with grazing patterns in uplant plant communities. Multiple regression models could not predict grazing distribution patterns with useful precision.

Proper distribution of livestock grazing is an integral part of effective range management. The goal of livestock distribution management is to gain maximum safe use over as wide an area as possible without causing serious damage to any portion within it. Mountain rangelands often exhibit complex combinations of topography, plant communities and successional stages, water distribution, and other habitat factors which create especially difficult grazing distribution problems. For instance, utilization may reach 75 to $80 \%$ on gently sloping drainages while steep slopes 150 m away receive $5 \%$ use or less (Phillips 1965 ). On a relatively small range unit of 690 ha in northern Utah, as much as $62 \%$ of the area received no use by cattle (Gonzalez 1964). A better understanding of the interactions between livestock behavior, natural habitat factors, and management factors should aid in developing more effective methods of livestock distribution.

This paper reports on a 3-year study of cattle distribution behavior. The objective of the study was to evaluate the effects of several physical, biological, and managerial factors on the patterns of cattle use of mountain rangelands. Direct observation and forage utilization sampling were used to quantify grazing patterns of cattle under both continuous and deferred-rotation grazing schemes.

\section{Study Area}

The study was conducted on the Upper Middle Fork Grazing Allotment of the Malheur National Forest in north-central Oregon from 1979 to 1981 . Elevations range from $1,160 \mathrm{~m}$ along the Middle Fork of the John Day River, which flows northwest through the Allotment, to over $2,300 \mathrm{~m}$ on the watershed boundaries. Topography is mountainous with slope gradients ranging from

\footnotetext{
Authors are graduate research assistant, professor, and associate professor, respectively, Department of Rangeland Resources, Oregon State University, Corvallis 9733i. Gillen is currently assistant professor, Department of Agronomy, Oklahoma State University, Stillwater 74078 and Miller is at the Eastern Oregon Agricultural Research Center, Burns, Oregon.

This report was submitted as Technical Paper No. 6985. Oregon Agricultural Experiment Station. The work was supported by the USDA-Forest Service Range Evaluation Project through the Pacific Northwest Forest and Range Experiment Station.

Manuscript accepted March 19, 1984
}

0 to $100 \%$.

Annual average precipitation ranges from $500 \mathrm{~mm}$ in the valley bottom to $1,020 \mathrm{~mm}$ at the highest elevations. Most of the precipitation falls as snow from November through April. Little precipitation is expected in July, August, and early September. During the summer grazing season, daytime maximum temperatures reach $20-30^{\circ} \mathrm{C}$ but frost may occur in any month.

Plant communities in the study area have been described by Hall (1973). For this study, the plant communities were combined into 6 general groups. Meadows were narrow communities (less than 30 $\mathrm{m}$ wide) found mostly along streams. Major dominants included Kentucky bluegrass (Poa pratensis), redtop (Agrostis stolonifera), various sedges (Carex spp.), and Baltic rush (Juncus balticus). Grassland communities occupied upland sites with shallow soils and limited water storage capacity. Bluebunch wheatgrass (Agropyron spicatum), Sandberg bluegrass (Poa sandbergii), and onespike danthonia (Danthonia unispicata) were major species on these sites.

The ponderosa pine (Pinus ponderosa)-Douglas-fir (Pseudotsuga menziesii) community group was located on the driest commercial timber sites in the area. It consisted of a variable mixture of ponderosa pine and Douglas-fir in the overstory with an understory dominated by elk sedge (Carex geyeri). Pinegrass (Calamagrostis rubescens) was nearly co-dominant with elk sedge on the better sites. The mixed conifer community group was similar to the ponderosa pine-Douglas-fir community group but occurred on more productive sites. Grand fir (Abies grandis) was a major overstory component along with ponderosa pine and Douglas-fir. Pinegrass and elk sedge dominated the understory with pinegrass generally contributing the larger amount.

The grand fir community group occurred on the wettest forest sites at the higher elevations. Grand fir was the major tree species. Understory dominants included huckleberries (Vaccinium spp.), pinegrass, and various shade tolerant forbs. The logged forest community group consisted of ponderosa pine-Douglas-fir or mixed conifer sites that had received $90-100 \%$ reductions in tree canopy within the last 15 years. Major herbaceous species included pinegrass, elk sedge, mountain brome (Bromus marginatus), orchardgrass (Dactylis glomerata), and intermediate wheatgrass (Agropyron intermedium).

Data were collected in 2 of the 6 pastures that comprise the Upper Middle Fork Grazing Allotment. The Butte Pasture included 4,675 ha with a general north-northeast aspect. This pasture was grazed continuously with 85 cow-calf pairs from early June to mid-October except in 1980, when grazing began in early July. The Caribou Pasture included 3,610 ha with a southsouthwest aspect. This pasture was grazed from early June to early August in 1979 and 1981 and from early August to mid-October in 1981 as part of a two pasture deferred-rotation grazing system. The Caribou Pasture was stocked with 200 cow-calf pairs.

\section{Methods}

\section{Direct Cattle Observations}

Cattle distribution was determined by actual observation from 1979 to 1981 using observation routes along existing roads. Start- 
Table 1. Proportion of cattle observed in different plant communities during three grazing periods. (PI = Preference Index).

\begin{tabular}{|c|c|c|c|c|c|c|c|c|c|}
\hline \multirow[b]{2}{*}{ Plant community } & \multicolumn{3}{|c|}{ Continuous grazing } & \multicolumn{3}{|c|}{ Early grazing } & \multicolumn{3}{|c|}{ Late grazing } \\
\hline & $\%$ Cattle & $\%$ Area & PI & $\%$ Cattle & $\%$ Area & PI & $\%$ Cattle & $\%$ Area & Pl \\
\hline meadow & $47 a^{2}$ & 5 & $9.4^{* 3}$ & $24 a$ & 3 & $8.0^{*}$ & $34 a$ & 3 & $11.3^{*}$ \\
\hline $\begin{array}{l}\text { grassland } \\
\text { ponderosa pine- }\end{array}$ & $18 \mathrm{~b}$ & 6 & $3.0^{*}$ & $5 b$ & 9 & 0.6 & $5 b$ & 9 & 0.6 \\
\hline Douglas-fir & $16 \mathrm{~b}$ & 17 & 0.9 & $23 a$ & 42 & $0.5^{*}$ & $24 c$ & 42 & $0.6^{*}$ \\
\hline mixed conifer & $16 \mathrm{~b}$ & 35 & $0.5^{*}$ & $11 \mathrm{c}$ & 24 & $0.5^{*}$ & $12 d$ & 24 & $0.5^{*}$ \\
\hline grand fir & $4 c$ & 37 & $0.1^{*}$ & - & - & - & - & - & - \\
\hline logged forest & - & 一 & - & $37 \mathrm{~d}$ & 22 & $1.7^{*}$ & $25 \mathrm{c}$ & 22 & 1.1 \\
\hline
\end{tabular}

1 based on 1001,1906 , and 583 observations for continuous, early, and late grazing, respectively.

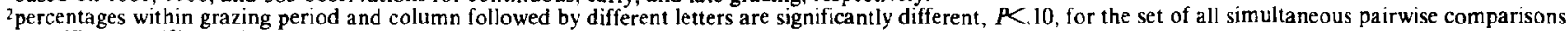
$3 *$ significantly different from $1.0, P<.05$.

ing times and directions of travel for the observation routes were allocated in a stratified random manner. Observations were made every third day and during all time periods from dawn until dusk. The number of cattle, cattle activity, plant community occupied, and map location were recorded for each cattle sighting. Additional information calculated from topographic maps included slope gradient (per cent) and trail distance to salt and water (meters).

Vegetation along the observation routes was mapped by community type following the classification of Hall (1973). Vegetation mapping extended out to the estimated limit of cattle visibility. A random sample of 100 points was placed within the observation boundaries of each observation route and the habitat characteristics of each sample point were determined to estimate the availability of habitat factors used to describe cattle location.

Cattle observations were totaled by plant community and compared to available community distributions within pastures by chi-square analysis. When the hypothesis of equality among distributions was rejected, the normal approximation to the binomial distribution (Snedecor and Cochran 1967) was used to test pairs of proportions within categories. The simultaneous probability level used for pairwise comparisons was $10 \%$. A Bonferroni approach to simultaneous testing resulted in a pairwise probability level of 1-3\% (Marcum and Loftsgaarden 1980).

Data were also expressed as preference indices since each class of the independent variables did not contain an equal proportion of the observation area. The preference index was defined as the ratio of the percentage of total animals observed within a particular class to the percentage of the total observation area within that class. This is the same concept as the relative preference index often used in animal diet selection studies (Krueger 1972). An index value greater than one indicated that more cattle were observed within a class than would have been expected by random use and was considered to imply positive animal preference for that class. Values less than 1 implied a particular class was not preferred.

\section{Upland Forage Utilization}

Fifty permanent sampling sites were located in upland plant communities in the Butte and Caribou Pastures by a stratified random procedure to represent the range of plant communities and topographic situations. In 1979, 25 sites were sampled in the Butte Pasture and 40 sites were sampled in the Caribou Pasture. Fifty sites were sampled in both pastures in 1980 and 1981 .

Forage utilization was estimated on each site at the end of the respective grazing period in each pasture. Utilization was estimated by the ocular-estimate-by-plot technique (Pechanec and Pickford 1937a) for all species occurring within $200.5-\mathrm{m}^{2}$ circular plots spaced along a $60-\mathrm{m}$ pace transect.

Herbaceous production was sampled on one-half of the permanent study sites. Production measurements were collected on transects that ran parallel to and were within $10 \mathrm{~m}$ of the utilization sampling transects. Ten evenly spaced $0.5-\mathrm{m}^{2}$ circular plots were measured per transect at the peak of standing crop. The dominant species were clipped and weighed for cach plot. Secondary species were estimated by the weight-estimate-per-plot method (Pechanec and Pickford 1937b). Herbaceous production plots were not protected from grazing; standing crop data were adjusted by forage utilization estimates to arrive at an estimate of ungrazed herbaceous production. Samples of all species were collected and dried at $50^{\circ} \mathrm{C}$ to a constant weight to express production estimates on an oven-dry basis. Production transects were then pooled within plant communities to estimate annual herbage production and species composition within communities.

Physical attributes estimated for all utilization sites included slope gradient; slope length to road, trail, or drainage bottom; distance to water and salt along the probable trailing route; and vertical distance to water and salt. Tree canopy cover was also measured at each site with a spherical densiometer (Lemmon 1957).

For statistical analyses, utilization was expressed as a weighted percentage estimate of grass utilization. This estimate was calculated by summing the products of percent utilization and percent composition by weight over all grass species. Upland scdges (mainly elk sedge) were included within the grass component. Grass utilization within plant communities was analyzed by completely randomized analysis of variance with unequal replications. The dependent variable of observed utilization and the quantitative independent site factors were subjected to correlation and multiple regression analyses. The data were stratified by pasture, ycar, and forage types for the analyses. Forage types were based on the major forage species and the general characteristics of the site and consisted of 3 groups: grassland, forest, and logged forest.

Data from each year were analyzed separately with similar results. The analyses were then combined over years in the Butte Pasture and over early and late grazing in the Caribou Pasture. Cattle observation data from the Butte Pasture in 1979 were deleted from the final analysis because of inadequate sample size.

\section{Results}

\section{Direct Cattle Observations \\ Plant Communities}

The most obvious feature of cattle use of plant communities under continuous grazing in the Butte Pasture was the high cattle preference for meadow communities (Table 1). This vegetation group had a preference index (PI) of greater than 9.0 with almost half of the animals observed on $5 \%$ of the total area. The grassland communities were also preferred although to a lesser extent than the meadow communities. The ponderosa pine-Douglas-fir communities were used in proportion to availability. Cattle avoided the mixed conifer and grand fir forests. Logged forest communities were not present in the continuously grazed pasture.

Under deferred-rotation grazing in the Caribou Pasture, meadow communities were also highly preferred with PI values rang- 
ing from 7.7 to 11.3 (Table 1). Late season grazing increased cattle use of the meadows. The logged forest communities were preferred in the early grazing period but were used as available in the late period. The forested communities were not preferred; however, the ponderosa pine-Douglas-fir forests should still be considered an important cattle use area since almost one-quarter of all cattle observations were made in those communities. Use of grassland communities was not significantly different from availability. Grand fir forest communities were not sampled in the deferredrotation pasture.

\section{Physical Factors}

Slope gradient was inversely associated with cattle preference for all grazing periods (Table 2). The high preference index for the

Table 2. Preference indices for slope gradient classes during three grazing periods as determined by direct cattle observations.

\begin{tabular}{cccc}
\hline $\begin{array}{c}\text { Slope gradient } \\
\text { (\%) }\end{array}$ & $\begin{array}{c}\text { Continuous } \\
\text { grazing }\end{array}$ & $\begin{array}{c}\text { Early } \\
\text { grazing }\end{array}$ & $\begin{array}{c}\text { Late } \\
\text { grazing }\end{array}$ \\
\hline S or less & 3.0 & 3.7 & 4.0 \\
$6-10$ & 5.3 & 2.9 & 4.8 \\
$11-15$ & 0.8 & 1.6 & 1.6 \\
$16-20$ & 0.8 & 1.1 & 0.6 \\
$21-30$ & 0.4 & 0.5 & 0.5 \\
31-45 & 0.3 & 0.4 & 0.4 \\
greater than 45 & 0.1 & 0.1 & 0.1 \\
\hline
\end{tabular}

6-10\% slope class in the continuously grazed pasture was the result of the most heavily used meadow having a $6 \%$ slope gradient. In the deferred-rotation pasture, late grazing tended to shift cattle preference to the lower slope gradients. Cattle appeared to avoid slope gradients in excess of $20 \%$ during all grazing periods.

Cattle preferred areas within $200 \mathrm{~m}$ of water and avoided areas greater than $600 \mathrm{~m}$ from water in the continuously grazed pasture (Table 3). A similar relationship was present in the deferredrotation pasture except for an unexplained avoidance of the 201$400 \mathrm{~m}$ distance class. Cattle preference shifted to the lower distance classes during late grazing. The shifts in both slope gradient and distance to water relationships can be attributed to the greater preference for the meadow communities during late grazing.

Distance from salt had little effect on cattle preference in the continuously grazed pasture (Table 3 ). In the deferred-rotation pasture, areas within $600 \mathrm{~m}$ of salt were slightly preferred or used as available while areas greater than $600 \mathrm{~m}$ from salt were not preferred. This relationship was similar between early and late grazing.

\section{Upland Forage Utilization \\ Plant Communities}

Considering only upland plant communities, grass utilization was most intense in the ponderosa pine-Douglas-fir forest under continuous grazing (Table 4 ). The grasslands and more heavily forested communities received half as much utilization as the ponderosa pine-Douglas-fir forests. Under early grazing in the deferredrotation pasture, logged forest communities received the heaviest grass utilization. The forested communities sustained about twothirds as much utilization as the logged sites while the grasslands were little used. Under late grazing, the upland communities maintained the same relative rankings for grass utilization. However, utilization levels were not discrete but formed a continuum from the logged forest communities to the grasslands.

\section{Individual Site Factors}

Although several site factors were correlated with grass utilization on forested sites, no single factor had a high association with grass utilization (Table 5). Many of the correlations in the continuously grazed pasture can be explained by plant community preferences noted earlier. Within the forests, the relatively more preferred ponderosa pine-Douglas-fir communities tended to have higher production, less pinegrass and more elksedge. The least preferred grand fir communities tended to be opposite in all of these categories. Correlations for the logged forest communities were generally larger than for the forest sites in the early period but fewer logged sites were sampled. Only one site factor, slope gradient on forested sites, was significantly correlated with grass utilization in the late grazing period. The negative association between grass utilization and percent elk sedge on logged sites indicates higher utilization on sites with smaller proportions of elk sedge and larger proportions of introduced pasture grasses. This relationship was reversed in the late period but the correlation is not significant. No site factors were significantly correlated with grass utilization on grassland sites within any of the grazing periods.

Several transformations of site factors were included in the correlation analyses. These included the natural logarithms of all distance, slope, and tree cover variables, the square root of all distance and slope variables, and the product of slope gradient and slope length. These transformations did not improve the correlation of any site factor with grass utilization.

The proportion of variation in grass utilization which could be accounted for by multiple regression models ranged from 0 to $55 \%$ for individual years and averaged $26 \%$ for the forest communities $(P<05)$. The number of site factors included in the individual regression models ranged from 2 to 4 . On the logged forest sites, the regression models accounted for 0 to $97 \%$ of the variability in grass utilization. High coefficients of determination were the result of large single factor correlations in the early grazing period (Table 5). However, these relationships should be considered tentative because of the limited sample size. Overall, it was felt that the regression models constructed for the forest and logged forest communities would not be useful in predicting grass utilization patterns in management situations.

\section{Discussion}

The extreme preference cattle exhibited for meadow communities in this study agrees with research reports from other mountain rangelands (Bryant 1982, Long and Irwin 1982, Roath and Krueger 1982) and makes these areas the major factor influencing grazing distribution. While these communities are certainly preferred by cattle, it should be pointed out that the preference indices were calculated on the basis of plant community area, not herbage production. The meadow communities produced 12-16 times as much herbage as the grasslands and forest communities and about

Table 3. Preference indices for distance classes to water and salt during three grazing periods as determined by direct cattle observations.

\begin{tabular}{|c|c|c|c|c|c|c|}
\hline \multirow[b]{2}{*}{$\begin{array}{c}\text { Distance } \\
(\mathrm{m})\end{array}$} & \multicolumn{3}{|c|}{ Water } & \multicolumn{3}{|c|}{ Salt } \\
\hline & $\begin{array}{l}\text { Continuous } \\
\text { grazing }\end{array}$ & $\begin{array}{c}\text { Early } \\
\text { grazing }\end{array}$ & $\begin{array}{l}\text { Late } \\
\text { grazing }\end{array}$ & $\begin{array}{c}\text { Continuous } \\
\text { grazing }\end{array}$ & $\begin{array}{c}\text { Early } \\
\text { grazing }\end{array}$ & $\begin{array}{l}\text { Late } \\
\text { grazing }\end{array}$ \\
\hline 200 or less & 1.8 & 1.9 & 2.1 & 1.2 & 1.2 & 1.2 \\
\hline $201-400$ & 1.2 & 0.5 & 0.7 & 0.8 & 1.4 & 1.1 \\
\hline $401-600$ & 1.2 & 1.0 & 0.8 & 0.6 & 1.2 & 1.7 \\
\hline $601-800$ & 0.4 & 0.8 & 0.4 & 1.5 & 0.6 & 0.4 \\
\hline greater than 800 & 0.3 & 0.6 & 0.5 & 1.4 & 0.3 & 0.3 \\
\hline
\end{tabular}


Table 4. Grass utilization (\%), number of sample sites (N), and herbage production ( $\mathrm{kg} / \mathrm{ha}$ ) for different upland plant communities during three grazing periods.

\begin{tabular}{|c|c|c|c|c|c|c|c|}
\hline \multirow[b]{2}{*}{ Plant community } & \multicolumn{2}{|c|}{ Continuous grazing } & \multicolumn{2}{|c|}{ Early grazing } & \multicolumn{2}{|c|}{ Late grazing } & \multirow{2}{*}{$\begin{array}{c}\text { Herbage } \\
\text { production }\end{array}$} \\
\hline & Utilization & $\mathbf{N}$ & Utilization & $\mathbf{N}$ & Utilization & $\mathbf{N}$ & \\
\hline grassland & $8 \mathrm{a}^{1}$ & 5 & la & 7 & $4 a$ & 7 & 240 \\
\hline ponderosa pine-Douglas-fir & $14 b$ & 18 & $10 \mathrm{~b}$ & 23 & $11 b c$ & 23 & 230 \\
\hline mixed conifer & $8 \mathbf{a}$ & 20 & $8 b$ & 13 & $7 a b$ & 13 & 209 \\
\hline grand fir & $6 a$ & 7 & - & - & - & - & 184 \\
\hline logged forest & - & - & $15 \mathrm{c}$ & 7 & $14 \mathrm{c}$ & 7 & 465 \\
\hline
\end{tabular}

' percentages within columns followed by different letters are significantly different, $P<.05$.

Table 5. Simple correlations between upland grass utilization and individual site factors on forest and logged forest sites during continuous, early, and late grazing periods.

\begin{tabular}{|c|c|c|c|c|c|}
\hline \multirow[b]{2}{*}{ Site factor } & \multirow{2}{*}{$\frac{\text { Forest }}{\text { Continuous grazing }}$} & \multicolumn{2}{|c|}{ Forest } & \multicolumn{2}{|c|}{ Logged forest } \\
\hline & & Early grazing & Late grazing & Early grazing & Late grazing \\
\hline herbage production ( $\mathrm{kg} / \mathrm{ha})$ & $.26 * * 1$ & .21 & .12 & .29 & -.45 \\
\hline$\%$ pinegrass & $-.24^{*}$ & .14 & -.03 & -.28 & -.14 \\
\hline$\%$ elksedge & $.30^{* *}$ & .02 & .15 & $-.68^{*}$ & .45 \\
\hline$\%$ tree canopy cover & .01 & $-.29^{*}$ & -.16 & -.62 & -.04 \\
\hline$\%$ slope & $-.24 *$ & $-.50^{* *}$ & $-.52 * *$ & -.58 & .15 \\
\hline slope length (m) & -.08 & -.04 & .08 & $-86^{* *}$ & -.48 \\
\hline trail distance to water $(\mathrm{m})$ & -.02 & .16 & -.18 & -.24 & -.36 \\
\hline vertical distance to water $(\mathrm{m})$ & -.08 & $-.25^{*}$ & -.22 & -.33 & .12 \\
\hline trail distance to salt $(\mathrm{m})$ & -.15 & -.20 & -.18 & $-.93 * *$ & -.25 \\
\hline vertical distance to salt $(\mathrm{m})$ & $-.37 * *$ & -.05 & -.14 & -.46 & -.02 \\
\hline number of sites sampled & 45 & 36 & 36 & 7 & 7 \\
\hline
\end{tabular}

$1 * P<.05, * * P<.01 ;$ correlations pooled over years.

6 times as much herbage as the logged forest and communities. The meadows could be expected to support higher relative cattle use because of their higher relative herbage production. However, since overall forage utilization averaged about $75 \%$ on the meadows versus $10 \%$ for the upland communities (Gillen 1982), differences in relative forage production did not explain all of the disproportionate use.

Significant differences in cattle use were found between upland plant community groups, indicating overall vegetation structure and composition were major factors influencing upland cattle distribution. Cattle made heaviest use of the logged forest and more open forest communities, which agrees with other reports from this region (Hedrick et al. 1968, Miller and Krueger 1976). It was felt this behavior was related to lower tree canopy coverage and increased forage production. Forage utilization was lower in grassland communities compared to open forests, which does not agree with previous work (Harris 1954). Vegetation in these shallow soil communities matured in late June after only 1 month of grazing, while herbage in the forest was still green. This differential forage maturity was probably most responsible for reduced grazing use of the grasslands, especially on south-facing sites in the deferred-rotation pasture. Late summer showers which stimulate green regrowth have been shown to increase cattle use on these grassland sites (Bryant 1982), a phenomenon also observed during this study.

Seasonal grazing appeared to affect plant community use in the deferred-rotation pasture. Late grazing reduced the logged forest sites from preferred communities to communities used in proportion to availability. An increase in cattle use of riparian meadows resulted. Removal of the trec canopy accelcrated plant growth on logged areas. By the time cattle entered the pasture in the late period, many of the grasses were mature and unpalatable. This was especially apparent for pinegrass, mountain brome and intermediate wheatgrass. Considerable amounts of useable herbage were lost because utilization on these species dropped nearly to zero. Utilization of the evergreen elk sedge also increased considerably in the late grazing period.

The ability to predict upland forage utilization patterns from site characteristics was limited under the conditions of this study. Forage utilization levels were light on upland plant communities with an average of $10 \%$ over all sites and a maximum of $36 \%$ on a single site. Cattle sign, including fecal droppings and hoof prints, was noted in virtually every part of the pastures, but large amounts seldom occurred on any single upland site.

As utilization levels decrease, the relative variation of utilization estimates often increases. This additional sampling variation makes the task of outlining utilization patterns more difficult. Even though cattle would be expected to exhibit grazing preferences most clearly under light stocking levels, practical sampling limitations may prevent a clear delineation of these grazing preferences. This is one reason for the general lack of fit in the mathematical models describing upland grazing distribution.

Several investigators have developed regression models relating forage utilization and various site factors. Cook (1966) obtained $R^{2}$ values of 0.56 for a single year and 0.38 for 3 years of pooled data on Utah foothill range. McDaniel and Tiedeman (198I) reported $R^{2}$ values of $0.38-.63$ in a study of sheep distribution on mountain range. Forage utilization ranged from $3 \%$ to $65 \%$. With forage utilization of $0-84 \%$, Clary et al. (1978) reported an $R^{2}$ value of 0.79 for a cattle distribution model in northern Arizona. It would appear that as the range in utilization increased, the proportion of explained variation increased, possibly because distribution patterns were sampled with greater precision.

The ability to predict cattle distribution also increases as the 
number of major habitat factors influencing distribution decreases and interactions become less complex. Mueggler (1965) controlled all but 2 site factors and achieved an $R^{2}$ value of 0.81 for cattle use on mountain grasslands. In a relatively small mountain pasture of 144 ha, Miller and Krueger (1976) developed a model accounting for $99 \%$ of the observed variation in cattle distribution patterns.

Correlation analyses pointed out slope gradient as the physical factor most consistently associated with cattle use of the landscape. This negative effect of slope gradient on cattle distribution is well known on mountain rangelands (Mueggler 1965, Cook 1966, Patton 1971, Van Vuren 1980). Water distribution was moderately associated with cattle preference as determined by direct observation. This was at least partly due to water being present in the highly preferred riparian meadows, but water was not totally responsible for this high preference. Water distribution had practically no association with cattle grazing patterns when only upland distribution was considered. Each pasture contained 3 perennial streams and several upland water developments. Other workers have reported similar results on relatively well-watered ranges (Julander and Jeffery 1964, Cook 1966, Clary et al. 1978).

Salt placement was inconsistently associated with cattle distribution. Some research reports have indicated little influence of salt placement on grazing behavior (Cook 1966, Wagnon 1968, Bryant 1982) while others have reported a much larger influence (Cook 1967, Bjugstad and Dalrymple 1968, Patton 1971, Roath and Krueger 1982). More controlled experimentation with salt distribution on mountain rangelands seems warranted.

Some of the factors associated with upland grazing distribution in this study can be modified through management activities. Some degree of forest canopy removal will create preferred grazing areas, especially when palatable pasture grasses are established. This type of manipulation should decrease cattle use of riparian zones and partially overcome the negative effects of slope gradient (Cook and Jeffries 1963). Trail construction can also decrease the effects of slope gradient (Patton 1971).

Grazing distribution patterns on mountain rangelands are difficult to predict with useful precision because they are influenced by such a complex of physical and biological factors, including animal social behavior. However, general relationships between plant communities, site factors, and cattle distributions have been discussed. Each of these factors should be considered when developing grazing plans, with the realization that every situation will have a different combination of factors. The use of grazing or land treatments which take advantage of the effects of desirable environmental factors on animal distribution or minimize the effects of undesirable factors could allow substantial improvement in the utilization and conservation of these mountain rangelands.

\section{Literature Cited}

Bjugstad, A.J., and A. Dalrymple. 1968. Behavior of beef heifers on Ozark ranges. Missouri Agr. Exp. Sta. Bull. B-870.

Bryant, L.D. 1982. Response of livestock to riparian zone exclusion. J. Range Manage. 35:780-785.

Clary, W.P., P.F. Ffolliott, and F.R. Larson. 1978. Factors affecting forage consumption by cattle in Arizona ponderosa pine forests. J. Range Manage. 31:9-10.

Cook, C.W. 1966. Factors affecting utilization of mountain slopes by cattle. J. Range Manage. 19:200-204.

Cook, C.W. 1967. Increased capacity through better distribution on mountain ranges. Utah Sci. 28:39-42.

Cook, C.W., and N. Jeffries. 1963. Better distribution of cattle on mountain ranges. Utah Farm and Home Sci. 24:48-49.

Gillen, R.L. 1982. Grazing behavior and distribution of cattle on mountain rangelands. Ph.D. Diss., Oregon State Univ., Corvallis.

Gonzalez, M.H. 1964. Patterns of livestock behavior and forage utilization as influenced by environmental factors on a summer mountain range. Ph.D. Diss., Utah State Univ., Logan.

Hall, F.C. 1973. Plant communities of the Blue Mountains in eastern Oregon and southeastern Washington. USDA Forest Serv. Pac. NW Region, R6 Area Guide 3-1. arris, R.W. 1954. Fluctuations in forage utilization on ponderosa pine ranges in eastern Oregon. J. Range Manage. 7:250-255.

Hedrick, D.W., J.A. Young, J.A.B. McArthur, and R.F. Keniston. 1968. Effects of forest and grazing practices on mixed coniferous forests of northeastern Oregon. Oregon Agr. Exp. Sta. Tech. Bull. 103.

Julander, O., and D.E. Jeffery. 1964. Deer, elk, and cattle range relations on summer range in Utah. Trans. N. Amer. Wildl. and Nat. Res. Conf. 29:404-414

Krueger, W.C. 1972. Evaluating animal forage preference. J. Range Manage. $25: 471-475$.

Lemmon, P.E. 1957. A new instrument for measuring forest overstory density. J. Forest 55:667-669.

Long, A.J., and L.L. Irwin. 1982. Elk-cattle interactions in the Bighorn Mountains, Wyoming. p. 553-563. In: J.M. Peek and P.D. Dalke, ed. Wildlife-Livestock Relations Symposium: Proc. 10. Univ. ldaho, Forest, Wildl., and Range Exp. Sta., Moscow.

Marcum, C.L., and D.0. Loftsgaarden. 1980. A nonmapping technique for studying habitat preferences. J. Wildl. Manage. 44:963-968.

McDaniel, K.C., and J.A. Tiedeman. 1981. Sheep use on mountain winter range in New Mexico. J. Range Manage. 34:102-104.

Miller, R.F., and W.C. Krueger. 1976. Cattle use on summer foothill rangelands in northeastern Oregon. J. Range Manage. 29:367-371.

Mueggler, W.F. 1965. Cattle distribution on steep slopes. J. Range Manage. 18:255-257.

Patton, W.W. 1971. An analysis of cattle grazing on steep slopes. Masters thesis, Brigham Young University, Provo, Utah.

Pechanec, J.F., and G.D. Pickford. 1937a. A comparison of methods used in determining percentage utilization of range grasses. J. Agr. Res. 54:753-765.

Pechanec, J.F., and G.D. Pickford. 1937b. A weight estimate method for the determination of range or pasture production. J. Amer. Soc. Agron. 29:894-904.

Phillips, T.A. 1965. The influence of slope gradient, distance from water, and other factors on livestock distribution on national forest cattle allotments of the Intermountain region. USDA Forest Serv. Intermount. Forest and Range Exp. Sta., Range Improvement Notes. 10:9-19.

Roath, L.R., and W.C. Krueger. 1982. Cattle grazing and behavior on a forested range. J. Range Manage. 35:332-338.

Snedecor, G.W., and W.C. Cochran. 1967. Statistical methods. Iowa. State Univ. Press.

Van Vuren, D. 1980. Ecology and behavior of bison in the Henry Mountains, Utah. Master of Sci. thesis, Oregon State Univ., Corvallis.

Wagnon, K.A. 1968. Use of different classes of range land by cattle. Calif. Agr. Exp. Sta. Bull. 838. 